\title{
Islamic Finance: Panacea for the Global Financial System?
}

\author{
Charles A. Rarick \\ Purdue University Calumet \\ Thaung Han \\ Purdue University Calumet
}

With the recent troubles in the global economy, some have proposed that a financial system based on sharia, or Islamic law is a better approach than traditional finance. The argument is made that Islamic finance is a safer approach, and less vulnerable to questionable financial transactions which may have led to the global recession beginning in 2008. This paper explores the basics of Islamic finance, and while agreeing that Islamic finance has an important role to play in the global financial system, concludes that it is not a viable substitute for traditional financial management.

\section{INTRODUCTION}

Beginning in September of 2008, the world watched as financial markets around the world began a dramatic downward slide. With news of troubled financial institutions hitting the streets, the problem expanded, and words such as “The Great Recession” or even "depression” began to be used. Further information revealed that much of the trouble could be blamed on the financial institutions in the West, especially in the United States. Troubled banks and investment firms holding "toxic assets" were singled out as the major sources of the economic crisis that was gripping the world. Citizens of many countries began to hear words such as "securitization," "credit default swaps," and other terms which were used to describe the causes of the economic downturn. It may have appeared to many that the financial system had become too complex, too greedy, nontransparent, and under-regulated. In the United States, many loans were made to unqualified borrowers, and those loans were then bundled and sold to other investors. When the housing market was making its astonishing rise, the problems were masked, however, once the market began to correct, the financial house of cards based on inflated values and questionable lending began to fall. The financial system appeared to be imploding, and questions were being raised about the fundamental structure of the traditional financial system. As investors and others began to search for answers, Islamic finance appeared as a possible panacea for the global financial system. Terms such as riba, sukuk, and mudaraba began to be heard in traditional financial circles as proponents of Islamic finance promoted their model of asset-based financing as a safer and more enduring approach.

\section{FUNDAMENTALS OF ISLAMIC FINANCE}

Central to the concept of Islamic finance is the prohibition of paying or receiving interest, or riba. According to Sheikh Nizam Yaquby, a noted expert in Islamic finance, "There is no sin in the Koran - 
not even drinking, not even fornication, not even homosexuality - which could be as abhorrent and serious as dealing with riba” (Power 2009 p. 70). Islamic finance is asset-based and requires the sharing of risk. Speculation and extreme positions of leverage are not allowed under Islamic law. In addition to riba, sharia prohibits ghar, or deception; maisir, or gambling; and haram, or investing in prohibited industries such as pork products, alcohol, and pornography.

There are a variety of ways of engaging in finance with Islamic principles, including personal financing and equity investments. As well, there are a variety of institutional arrangements, from an Islamic window at a traditional financial institution to a full- fledged Islamic bank. Perhaps the best known and the most successful of the Islamic financial instruments is the sukuk, the Islamic equivalent of a bond. Worldwide Islamic financial assets are estimated to be in the range of $\$ 1$ trillion and could quadruple in the next few years (Hanware 2009). Without the ability to charge or receive interest, Islamic finance has had to become more creative. A number of new financial arrangements have been developed including the murabaha. A Murabaha is an arrangement whereby a bank purchases an asset, such as real estate, for a client with the understanding that the client will buy the asset over time with an allocation built in the payments for profit. Other arrangements are provided for leasing an asset or providing capital to a business. In the case of business capital, the financial institution takes partial ownership instead of interest payments (Nouel 2007). With the growth of Islamic finance, institutions have been developed across the world to offer financial services to customers who wish to comply with sharia, or Islamic law. According to the International Monetary Fund (IMF) there are over 300 Islamic financial institutions in over 50 countries (Sole 2007) and given the current trends, it is reasonable to conclude that the numbers will continue to grow in the coming years.

A number of cities have become centers for Islamic finance (Figure 1), most of which are in countries with a large percentage of the population that is Muslim. Islamic finance is, however, also a growing market for financial institutions outside predominately Muslim countries. Not all Muslim countries, however, are receptive to Islamic finance. Egypt and Morocco are two examples. Egypt's government has taken a significant controlling position of the country's Islamic banks over fear of the spread of Islamic fundamentalism and this has hampered, in part, the development of Islamic banking in the country (Mouawad 2009). The government of Morocco has been reluctant to allow Islamic banking also, for much the same reason as Egypt. In some countries such as India and Nigeria, where conflict between Muslims and non-Muslims is a problem, Islamic banking has also not been allowed to develop (Modi 2007).

Kuala Lumpur established itself early as a major Islamic banking center, and has been successfully conducting Islamic financial transactions for over thirty years. Kuala Lumpur gained financial assets after the terrorist attacks in the United States in 2001, as capital flight from the United States took place in response to the perception of possible seizure of banking assets held by wealthy Muslims. Recently Singapore has taken steps to challenge Kuala Lumpur and to become the Islamic financial capital of Asia (International Financial Law Review 2009). Islamic finance is believed to be managing over a trillion dollars in assets, however difficulties arise in securing accurate statistics (Al-Salem 2008). While exact figures are hard to come by, there isn't much doubt that as many oil rich states became even wealthier with the increase in crude oil prices, Western banks and other financial institutions in the West began to take notice and to establish financial services that were sharia compliant. In addition to the increasing price of crude oil, the advancement of technology and online banking has made it feasible to establish financial centers that can serve clients from across the globe. 


\section{FIGURE 1 \\ TOP ISLAMIC CAPITAL MARKETS}

\author{
Kuala Lumpur, Malaysia \\ Dubai, UAE \\ Manama, Bahrain \\ Doha, Qatar \\ London, England \\ Singapore
}

\author{
Islamic Assets \\ $\$ 50.0 \mathrm{~B}$ \\ $\$ 46.3 \mathrm{~B}$ \\ $\$ 16.4 \mathrm{~B}$ \\ $\$ 14.8 \mathrm{~B}$ \\ $\$ 10.0 \mathrm{~B}$ \\ $\$ 1.80 \mathrm{~B}$
}

Percent of Sector
12.9
13.5
6.5
18.2
.05
6.5

L. Laurent. Forbes.com. April 21, 2008.

\section{ISSUES WITH ISLAMIC FINANCE}

While as we have seen through recent events, the traditional model of finance is not without its problems, however, Islamic finance also has its drawbacks as well. Is lamic finance can be seen as simply the repackaging of traditional financial instruments to look like they are sharia compliant. A study by the Accounting and Auditing Organization for Islamic Financial Institutions (AAOIFI) reported that 85\% of bonds sold as compliant with sharia were in fact not compliant (Power 2009). Islam has different branches and different schools of thought and different interpretations have emerged as to what is allowed under sharia. In addition to problems of consistency and legitimacy, problems include the lack of standardization, the limited number of financial instruments allowed under sharia, the shortage of qualif ied scholars to evaluate proposed investments, prohibitions that tend to limit liquidity, quantity, and diversification of assets, and a system which lacks a unified regulatory authority.

Liquidity is a concern in Islamic finance, as well as diversification, risk management, and availability of capital and its cost. Since it is essentially an asset and long term based financial system, problems with liquidity can arise in Islamic finance. Money markets provide liquidity to financial institutions, and the money market system by its very nature is interest based. In addition, by limiting the source of funds available to any individual or organization, the supply of funds would be reduced, and in theory, raise the cost of capital (Figure 2). If investors had availability to all financial markets (S) the cost of capital would be lower than those who operate in a restricted arena (SI). Likewise, by limiting the investments which are possible due to sharia restrictions, the level of diversification is reduced, and in theory, risk is increased (Figure 3). By limiting asset holdings to only those which are sharia compliant, and limiting different variations of financial instruments, fewer choices decrease the chance to diversify. Less diversification generally is associated with greater risk.

One of the investment alternatives which is generally not available in Islamic finance is the deviates market. Sharia prohibits speculation and puts into question the use of derivates and other non-asset based financial instruments. While there is a move to create sharia compliant derivates by the International Swaps and Derivates Association (Flynn 2008 \& Jobst 2009), the interpretation of Islamic law concerning speculation makes this task difficult and subject to controversy. While close approximations of a derivates market may be possible, a need exists for greater transparency, legal frameworks, and standardization (Hesse, Jobst, \& Sole 2008 \& Jobst 2007). This is true not only in derivates, but in the entire system of Islamic finance.

Another concern in Islamic finance is that the number of qualified people who can issue approval on Islamic financial instruments is very small. Ram (2008) reports that only 20 people are qualified to make such judgments, given the need for extensive knowledge of Islamic law, training in advanced finance, and language proficiency. This shortage of qualified evaluators means that sharia compliance boards of financial institutions have little choice for selection, and fees for such services can be high. It is also common for these elite scholars to sit on a number of different boards, creating at least the perception of a possible conflict of interest. 
FIGURE 2

\section{SUPPLY OF CAPITAL}

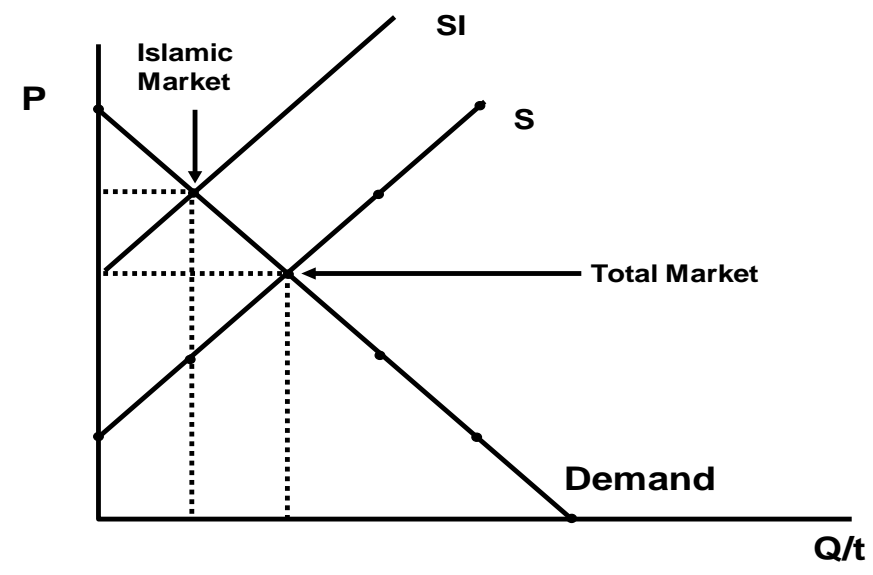

FIGURE 3

RISK AND DIVERSIFICATION

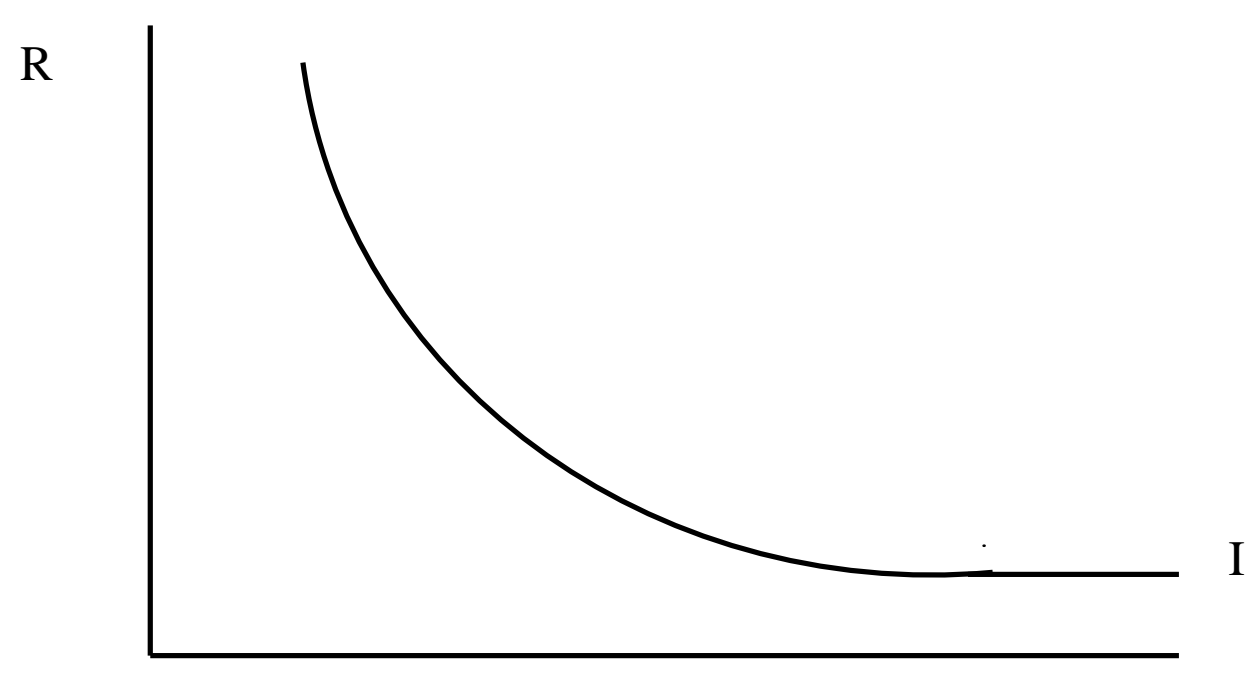

$\mathrm{N}$

Another issue which faces Islamic finance is the perception that some banks are involved in some way with terrorist groups. Such was the case of Prince Muhammad al-Faisal Saud and the company he founded, DMI. Among the assets of DMI are Islamic banks which have been accused of aiding the flow of money to Al Qaeda organizations (Thomas 2007). While the evidence is not strong to support such charges, Islamic banking is linked in the minds of some as facilitators of terrorist groups. Additionally, an asset based system of financial management has the potential for greater moral hazard with the practice of 
equity sharing and leasing. Individuals seeking capital may feel less responsible for the assets if they do possess complete ownership.

While Islamic finance has problems with liquidity, diversification, and other issues, perhaps the greatest issue facing the niche market of finance is the lack of standardization and regulation. Modi (2007) states that the most pressing issue facing Islamic finance is the need for standardized regulation, as well as the integration of the fragmented Islamic banking system. Speaking to the issue of standardization, Amol Prabhu, a member of the Islamic Documentation Committee of the International Islamic Finance Market, "There is not a lot of black and white in all of this. There is a lot of grey. Sometimes we find that the same issues occur in different transactions but are dealt with in completely different ways" (International Financial Law Review 2008). Some have argued that regulation of Is lamic finance should focus on the manner in which financial activities are carried out, rather than the substance of those activities (Henderson 2007). This would make regulation similar to that found in non-Muslim countries. Such a system appears to be working in Dubai, and could perhaps be a model for the rest of the Islamic world.

Another risk, not especially limited to Islamic finance, is holding real estate assets in a declining market. While Islamic banks were not caught up in the massive holding of "toxic assets" because of the lack of securitized debt (Khalaf 2009), holding assets in large quantities in a declining market is worrisome. Customers of Islamic banks could suffer a loss even if the bank does not fail due to the profit and loss sharing scheme of the system (Modi 2007). In addition to the above mentions problems, Is lamic banks are not immune to some of the same problems that plagued Western banks with respect to playing fast and loose with financial regulations and engaging in fraudulent practices.

Islamic finance has been growing at an impressive rate in recent years and appears to have been able to deal the problems mentioned in this paper. While research is somewhat limited in terms of specific examples, a study on Islamic banks in Pakistan showed that these banks were able to mainta in good financial performance, adequate liquidity, and better risk management (Siddiqui 2008). Islamic finance has appeal beyond just to the needs of followers of Islam. The prohibitions against certain investments could also appeal to investors concerned with socially responsible investing. Islamic finance may in fact be less risky for investors as well. A recently published report found that the Dow Jones Islamic Index (DJIS) outperformed the Dow Jones World Index (DJIM) during the period of 1996-2005 (Al-Zoubi \& Maghyereh 2007). The lower risk was attributed to the asset-based and risk-sharing model of Islamic finance. Islamic banking will probably continue to grow and satisfy the market for those who want, or need, to comply with the requirements of sharia.

\section{MANAGERIAL IMPLICATIONS}

While Islamic finance is an interesting and needed niche in the financial industry, it appears not likely to be a substitute for traditional finance. While much is appealing about Islamic finance, it does not seem capable of supporting the complexity of the global financial system. The fact that money itself is not viewed as an asset in its own right makes traditional concepts in financial management such as the time value of money less useful. Traditional techniques of financial management have to be radically altered to fit the Islamic view of money. As a niche market appealing to followers of Islam, as well as those concerned about investing in what may be socially unacceptable investments, Islamic finance appears to be a good alternative. In its present state, however, Islamic finance suffers from a number of problems which do not make it a panacea for the global financial system. Issues of standardization and regulation, liquidity, diversification, shortages of qualified overseers, and the negative perceptions are some are the reasons that Islamic finance will remain only a niche in the financial services industry.

\section{REFERENCES}

Al-Salem. (2008). The size and scope of the Islamic Finance industry. International Journal of Management, 25(1), 124-130. 
Al-Zoubi H. and A. Maghyereh. (2007). The relative risk performance of Islamic finance: A new guide to less risky investments. International Journal of Theoretical and Applied Finance, 10(2), 235-249.

Flynn, S. (2008). An Islamic capitalism. International Financial Law Review, July.

Hanware, K. (2009). You can bank on it: Islamic finance is the fastest growing phenomenon. McClatchyTribune Business News, March 23.

Henderson, A. (2007). Limiting the regulation of Islamic finance: Lessons from Dubai. Law and Financial Markets Review, 1(3), 213-220.

Hesse, H. A. Jobst, and J. Sole. (2008). Trends and challenges in Islamic finance. World Economics, 9(2), 175-193.

(2008). Uniting Islamic finance. International Financial Law Review, April.

(2009). Growth of Islamic finance. International Financial Law Review, March.

Jobst, A. (2007). The economics of Islamic finance and securitization. Journal of Structured Finance, 13(1), 6-27.

Jobst, A. (2009). Derivatives in Islamic finance. Islamic Economic Studies, 15(1). (Forthcoming) Available at SSRN:http:/ssrn.com.

Khalaf, R. (2009). Islamic finance must learn to resolve inner tensions. Financial Times, March 31.

Laurent, L. (2008). Capitals of Islamic finance. Forbes.com, April 21.

Modi, V. (2007). Writing the rules: The need for standardized regulation of Islamic finance. Harvard International Review, Spring.

Mouawad, S. (2009). The development of Islamic finance: Egypt as a case study. Journal of Money Laundering, 12(1), 74.

Nouel, G. (2007). Alternative finance products. International Law Review, May.

Power, C. (2009). Faith and the market. Foreign Policy, January/February, 70-75.

Ram, V. (2008). The enforcers. Forbes. April 21.

Siddiqui, A. (2008). Financial contracts, risk, and performance of Islamic banking. Managerial Finance, 34(10), 680-694.

Sole, J. (2007). Introducing Islamic banks into conventional banking systems. IMF Working Paper, July.

Thomas, L. (2007). Islamic finance and its critics. New York Times, August 9. 